\title{
A Note on the Dext
}

Unless otherwise indicated, all the references to Strindberg's works are to Samlade skrifter, ed. John Landquist ( 55 vols.; Stockholm, 1912-1927). The volume number appears in italics, the page numbers in roman (i.e., 22, 77, means volume 22, page 77 ).

The translations are my own with two exceptions. In chapter v, "The Peoplc of Hemsö," in which matters of style are elaborated upon, I have used Elspeth Harvey Schubert's beautiful translation with its remarkable fidelity to the original (Stockholm: Bonniers, 1959), cited as EHS in the text. In chapter xi, "Inferno," I have used Mary Sandbach's excellent translation because it is based on both the French and Swedish texts, an admirable compromise in my estimation (London: Hutchinson, 1962); cited as MS in the text.

In chapter vi, "The Defense of a Fool," my translations are based on Tage Aurell's Swedish version En däres försvar- 
Xviii $\quad A$ NOTE ON THE TEXT

stal (Stockholm: Bonniers, 1962), cited as TA in the text. Had Evert Sprinchorn's A Madman's Defense (New York: Anchor Books, 1967) been available at the time of writing, I would have used it in this chapter as the novel poses textual problems similar to those of Inferno and it is a fine translation of Strindberg's original Le plaidoyer d'un fou.

Brev in the notes refers to August Strindberg, Brev, ed. Torsten Eklund (9 vols.; Stockholm: Bonniers, 1947-1966). 